\section{Commentary: The beat goes on... Beating-heart simulators continue to evolve but have yet to arrive}

\author{
David D. Yuh, MD, FACS, FACC \\ "Certainly, it cannot matter as much who does the \\ operation, as how it is done."
}

As a Stanford cardiothoracic surgical resident, I was privileged to witness the incisive wit and wisdom of many aphorisms and observations by Norman Shumway. Widely acknowledged as a pioneer of modern cardiac surgical resident training, this quotation from his Presidential Address at the 67th Annual Meeting of the American Association for Thoracic Surgery ${ }^{1}$ succinctly reflects his rejection of outdated paternalistic apprenticeships in favor of immersive hands-on, learn-by-doing technical training. Simulator training represents an adaptation of this approach. Unfortunately, the fidelity of simulator platforms to actual operative conditions, particularly in cardiac surgery (eg, tissue quality, blood flow, motion), generally entails increased cost and complexity. In their article in this issue of the Journal, $\mathrm{Wu}$ and colleagues ${ }^{2}$ describe the design and application of a relatively low-cost beating heart simulator platform for offpump coronary artery bypass grafting (OP-CAB).

The described simulator provides an effective platform for developing basic coronary anastomotic skills; however, it does fall short in several important areas as an OP-CAB simulator. First, cardiac rotation and stabilizer positioning maneuvers, critical in the safe and successful conduct of OP-CABG, are not simulated in this platform, nor are the sometimes near-vertical angles frequently encountered in grafting inferior or lateral wall vessels in OP-CAB.

Despite these limitations, however, the most substantive disadvantage with this platform may lie in its lack of portability for the trainee. "Distributed practice," a strategy of learning that makes use of smaller increments of study and practice over a longer time period, is generally considered more effective for long-term learning and retention

From the Department of Surgery, Stamford Hospital, Stamford, Conn.

Disclosure: Author has nothing to disclose with regard to commercial support.

Received for publication March 16, 2020; revisions received March 16, 2020; accepted for publication March 17, 2020; available ahead of print April 6, 2020.

Address for reprints: David D. Yuh, MD, FACS, FACC, Department of Surgery, Stamford Hospital, One Hospital Plaza, PO Box 9317, Stamford, CT 06904 (E-mail:

DYuh@stamhealth.org).

J Thorac Cardiovasc Surg 2021;161:1886-7

$0022-5223 / \$ 36.00$

Copyright (c) 2020 by The American Association for Thoracic Surgery

https://doi.org/10.1016/j.jtcvs.2020.03.107

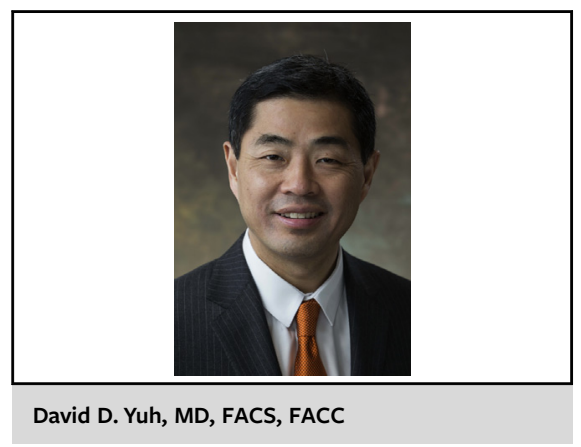

CENTRAL MESSAGE

Fidelity to operating conditions, including cardiac motion, reproducibility, and cost, highlight this OP-CAB simulator, but its lack of portability may limit its effectiveness as a training platform.

of knowledge and skills than the "massed practice" approach $^{3,4}$ necessitated by the authors' nonportable simulation model and training format. Fann and colleagues ${ }^{5}$ used this learning strategy effectively in designing a cardiac surgery simulation curriculum facilitated by portable coronary anastomotic simulators for distributed technical practice at home. Improvement in anastomotic skills over time in both static and beating-heart models were achieved using performance criteria very similar to those used by $\mathrm{Wu}$ and colleagues.

Notably, the residents trained on this beating-heart simulator performed more favorably than those trained on the non-beating-heart platform at the study's conclusion, particularly with criteria directly related to needle handling. However, I do not necessarily agree with the authors' notion that using the beating-heart simulator and excluding the static platform might improve training efficiency and outcomes. I would favor initial distributed learning of anastomotic technique facilitated by a static, portable simulator platform, because residents do not possess the same degree of technical dexterity early in their training.

Finally, the Wu group's use of disinfected balloon pump catheters and human saphenous vein remnants likely would be problematic in many institutions outside of China. Unused balloon pumps and synthetic saphenous vein conduits are alternatives; however, these would entail additional costs.

The authors should be congratulated on developing this low-cost beating-heart model and incorporating it in their residency training program. Aside from its advantages 
and disadvantages, it undoubtedly provides valuable, reproducible training for OP-CAB.

\section{References}

1. Shumway NE. Some thoughts from the other side of the table, or the last Presidential Address. J Thorac Cardiovasc Surg. 2011;142:1296-8.

2. Wu S, Ling Y-P, Zhao H. Experience with porcine beating-heart simulator for coronary artery bypass surgery residency training. J Thorac Cardiovasc Surg. 2021;161:1878-85.
3. Donovan JJ, Radosevich DJ. A meta-analytic review of the distribution of practice effect: now you see it, now you don't. J Appl Psychol. 1999;84: 795-805.

4. Moulton CA, Dubrowski A, MacRae H, Graham B, Grober E, Reznick R. Teaching surgical skills: what kind of practice makes perfect? Ann Surg. 2006;244: 400-9.

5. Fann J, Caffarelli AD, Georgette G, Howard SK, Gaba DM, Youngblood P, et al Improvement in coronary anastomosis with cardiac surgery simulation. J Thorac Cardiovasc Surg. 2008;136:1486-91.

\section{See Article page 1878.}

\section{Commentary: Getting to Carnegie Hall}

\author{
Dawn S. Hui, MD, ${ }^{\mathrm{a}}$ and Richard Lee, MD, $\mathrm{MBA}^{\mathrm{b}}$
}

In 1878, the Russian composer Pytor Ilyich Tchaikovksy completed composition of his Violin Concerto in D Major (Op. 35). For the first 3 years, the concerto was not publically performed because the Czar's court violinist Leopold Auer reportedly declared it unplayable. Since then, it has become not only a standard in the repertoire of professional violinists but also among the most frequently performed violin concertos. ${ }^{1}$ This radical transformation may be tied to late 19th century pedagogical advancements in violin playing. Although Auer did eventually perform and teach the concerto, of the 3 contemporary violin treatise authors with the greatest influence on modern pedagogy, Auer focused the least on technical aspects. ${ }^{2}$

In human technical skills performance, skills that do not primarily rely on physiology (eg, strength and flexibility) or adjunctive technology must look even more to a systematic method of training. In cardiac surgery, opportunities for

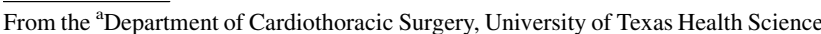
Center at San Antonio, San Antonio, Tex; and ${ }^{\mathrm{b}}$ Division of Cardiothoracic Surgery, Department of Surgery, Medical College of Georgia, Augusta University, Augusta, $\mathrm{Ga}$.

Disclosures: The authors reported no conflicts of interest.

The Journal policy requires editors and reviewers to disclose conflicts of interest and to decline handling or reviewing manuscripts for which they may have a conflict of interest. The editors and reviewers of this article have no conflicts of interest.

Received for publication Aug 24, 2020; revisions received Aug 24, 2020; accepted for publication Aug 25, 2020; available ahead of print Aug 31, 2020.

Address for reprints: Richard Lee, MD, MBA, Department of Surgery,

Medical College of Georgia, 1120 15th St, BA-4300, August, GA 30912

(E-mail: RICKLEE@augusta.edu).

J Thorac Cardiovasc Surg 2021;161:1887-8

0022-5223/\$36.00

Copyright (C) 2020 by The American Association for Thoracic Surgery

https://doi.org/10.1016/j.jtcvs.2020.08.081
}

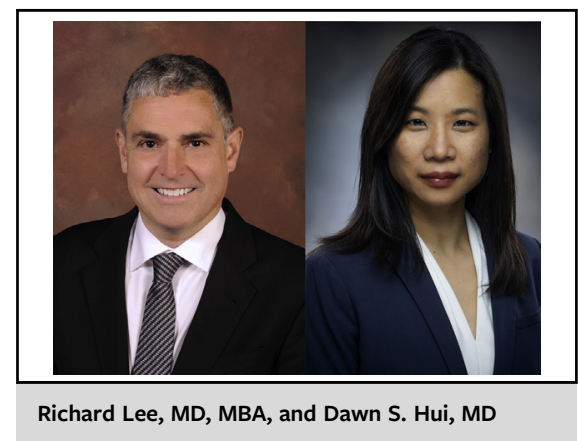

CENTRAL MESSAGE

Research in technical skills

training should account for the various aspects of cognitive load. Study designs may not be able to control or adjust for some confounding aspects.

technical skill training have traditionally occurred in an apprenticeship model, with experience gained during actual patient care. Increasing patient risk profiles and scrutiny of outcomes has led to investigations of simulation as an adjunctive method of training. ${ }^{3}$ This has challenges of fidelity, reproducibility, cost, and efficacy. Hence, widespread standardized simulation remains in evolution more than a decade after its role in cardiothoracic surgical training was envisioned. ${ }^{4}$

$\mathrm{Wu}$ and colleagues ${ }^{5}$ report their findings of a randomized study of trainees who were novices to coronary artery bypass grafting (CABG), comparing training on a beating heart model with a nonbeating model. Participants were tested on both models after 3 months of training. Significant findings were that those who trained on beating heart models improved to a greater degree in use of needle holder 